\title{
Transfer of the misnamed [Alysiella] sp. IAM 14971 (=ATCC 29468) to the genus Moraxella as Moraxella oblonga sp. nov.
}

\author{
Cheng-Hui Xie and Akira Yokota \\ Institute of Molecular and Cellular Biosciences, The University of Tokyo, 1-1-1 Yayoi, \\ Bunkyo-Ku, Tokyo 113-0032, Japan
}

Correspondence

Cheng-Hui Xie

aa37116@mail.ecc.u-tokyo.ac.jp

\begin{abstract}
Phylogenetic analysis based on 16S rRNA gene sequences revealed that [Alysiella] sp. IAM 14971 (=ATCC 29468) is closely related to the genus Moraxella of the $\gamma$-Proteobacteria (96-97\% similarity). The newly obtained phenotypic data also indicate that [Alysiella] sp. IAM 14971 is distinct from the genus Alysiella and similar to the genus Moraxella. On the basis of these results, the strain should be classified in the genus Moraxella, as Moraxella oblonga sp. nov. The type strain is IAM $14971^{\top}\left(=\right.$ ATCC $\left.29468^{\top}\right)$.
\end{abstract}

[Alysiella] sp. IAM 14971 ( = ATCC 29468) was isolated from the oral cavity of a sheep and identified by Kuhn (Gherna et al., 1989). Rossau et al. $(1986,1989,1991)$ argued that this strain was not at all related to the type strain of Alysiella filiformis (IAM $14895^{\mathrm{T}}$ ) based on the studies of rRNA cistron similarities and DNA hybridization levels. A. filiformis was identified as a member of the $\beta$-Proteobacteria based on phylogenetic analyses of the 16S rRNA gene sequence available from the GenBank database. The aim of this study was to identify the exact taxonomic position of [Alysiella] sp. IAM 14971 (=ATCC 29468). In this report, we present substantial evidence, mainly from the $16 \mathrm{~S}$ rRNA gene sequence, fatty acid composition, quinone system analysis and biochemical tests, suggesting that [Alysiella] sp. IAM 14971 belongs to the genus Moraxella of the $\gamma$-Proteobacteria.

The genus Moraxella Lwoff 1939, which comprises opportunistic bacterial pathogens, includes 15 authentic species to date. The genus was reclassified into two subgenera based on the shape of the cells (coccus and rod): Branhamella and Moraxella (Bøvre, 1979). The species with coccus-shaped cells are Moraxella (Branhamella) catarrhalis, Moraxella (Branhamella) caviae, Moraxella cuniculi and Moraxella (Branhamella) ovis. The species with rod-shaped cells are Moraxella (Moraxella) atlantae, Moraxella (Moraxella) bovis, Moraxella boevrei, Moraxella canis, Moraxella caprae, Moraxella equi, Moraxella (Moraxella) lacunata, Moraxella lincolnii, Moraxella (Moraxella) nonliquefaciens, Moraxella (Moraxella) osloensis and Moraxella saccharolytica.

The reference strains $A$. filiformis IAM $14895^{\mathrm{T}}$ (=NCTC

Published online ahead of print on 20 August 2004 as DOI 10.1099/ ijs.0.63250-0.

The GenBank/EMBL/DDBJ accession number for the 16S rRNA gene sequence of Moraxella oblonga IAM $14971^{\top}$ is AB087260.
$\left.10282^{\mathrm{T}}\right)$, A. filiformis IAM $14968^{\mathrm{T}}\left(=\right.$ ATCC $\left.15532^{\mathrm{T}}\right)$ and [Alysiella] sp. IAM 14971 (=ATCC 29468) were used in this study. Bacterial strains were incubated in ATCC medium 687 at $37^{\circ} \mathrm{C}$. For electron microscopy, cells grown on solid medium were fixed in a solution of $1 \%$ glutaraldehyde in $0.01 \mathrm{M}$ phosphate buffer $\mathrm{pH} 7.2$ for $2 \mathrm{~h}$ at room temperature. Cells were spread on the slide and air-dried. Water was removed gradually by suspending the samples in an acetone series (30, 50, 70, 90, 95 and $100 \%)$ and $100 \%$ 2-methyl-2-propanol. Samples were freeze-dried, sputtercoated with platinum under a vacuum and observed with a model Hitachi S4500 scanning electron microscope. API 20NE and 50CHL microtest galleries were used to determine the physiological and biochemical characteristics. The API strips were incubated for 2 days at $37^{\circ} \mathrm{C}$. Cellular fatty acid methyl esters were prepared, separated and identified by using the Microbial Identification system as described by Xie \& Yokota (2003). The respiratory quinone system was extracted and characterized by HPLC (Shimadzu), and the genomic DNA extraction, PCR-mediated amplification of the 16S rRNA gene and sequencing of the PCR products were carried out as described previously (Xie \& Yokota, 2003). The 16S rRNA gene sequence of [Alysiella] sp. IAM 14971 (1273 bp) was determined and compared with the sequences obtained from the DDBJ and GenBank. The sequences were aligned using the CLUSTAL W software package (Thompson et al., 1994), and the evolutionary distances and $K_{\text {nuc }}$ value (Kimura, 1980) were generated. Alignment gaps and ambiguous bases were not taken into consideration when the 16S rRNA gene nucleotides were compared. The phylogenetic trees were constructed using the neighbour-joining method (Saitou \& Nei, 1987). The topology of the phylogenetic tree was evaluated by the bootstrap resampling method of Felsenstein (1985) with 1000 replicates. The similarity values were calculated using PAUP* 4.0b1 (Swofford, 1998). 
The scanning electron micrograph of [Alysiella] sp. IAM 14971 shows that the cells are cocci that are linked in chains of $\geqslant 30 \mu \mathrm{m}$ in length. The cells are $0 \cdot 48-1 \cdot 2 \mu \mathrm{m}$ in diameter (Fig. 1a). The morphology of the chains of cocci is quite different from that of other species of the genus Moraxella, which are rod- or coccus-shaped, and also different from that of the multicellular filamentous A. filiformis, which has palisade organization in the middle of individual cells (Fig. 1b). [Alysiella] sp. IAM 14971 has similar biochemical and chemotaxonomic characteristics to other species of the genus Moraxella (shown in Table 1): the quinone system (Q-8); the presence of catalase and oxidase activity; and the absence of indole production and urea hydrolysis. [Alysiella] sp. IAM 14971 and Moraxella species cannot produce acid from glucose, but A. filiformis can. [Alysiella] sp. IAM 14971 can produce acid from mannitol, adonitol, inositol, rhamnose, arabinose, sucrose and maltose, which is different from A. filiformis (data not shown). The major cellular fatty acids of [Alysiella] sp. IAM 14971 are $16: 0(26 \cdot 7-27 \cdot 0 \%)$, $16: 0 \mathrm{~N}$ alcohol $(22 \cdot 4-23 \cdot 2 \%)$ and $16: 1 \omega 7 c(10 \cdot 2-12 \cdot 6 \%)$,
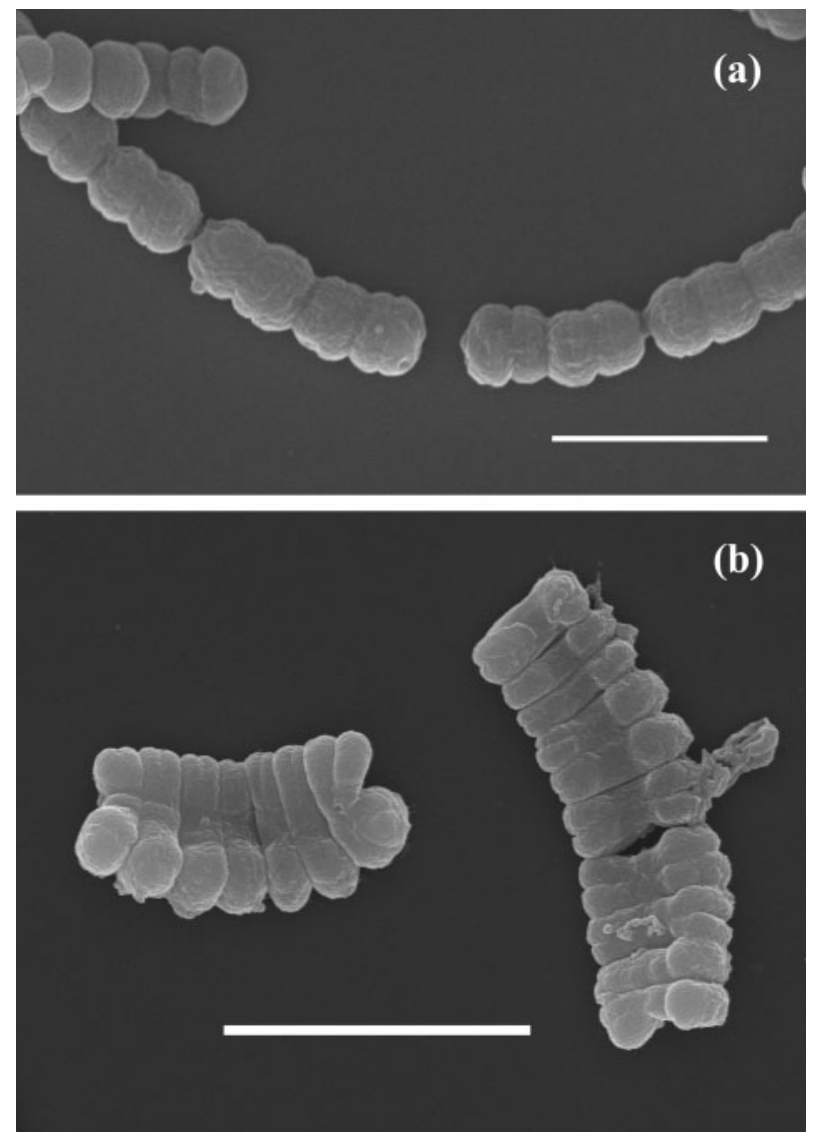

Fig. 1. Scanning electron micrographs of (a) Moraxella oblonga sp. nov. IAM $14971^{\top}$ and (b) A. filiformis IAM $14968^{\top}$. (a) The cocci are linked in chains. Bar, $2.4 \mu \mathrm{m}$. (b) The individual cells are of the same width, while those in the middle filament are sunk and appear ribbon-like. The ends of the individual filaments are square. Bar, $4 \mu \mathrm{m}$.
$18: 1 \omega 9 c(7 \cdot 9-8 \cdot 1 \%), 18: 3 \omega 6 c(6,9,12)(6 \cdot 7-9 \cdot 8 \%), 12: 0$ $(4 \cdot 2-4 \cdot 3 \%), \quad 18: 2 \omega 6,9 c(3 \cdot 9-4 \cdot 1 \%), 10: 0(2 \cdot 9-3 \cdot 7 \%)$, $14: 0(2 \cdot 1-2 \cdot 2 \%)$ and $18: 0(2 \cdot 4-3 \cdot 5 \%)$; the major hydroxy fatty acid is $3 \mathrm{OH}-12: 0(3 \cdot 0-3 \cdot 7 \%)$. [Alysiella] sp. IAM 14971 and Moraxella species possess 10:0 and 16:0 N alcohols, but A. filiformis does not. The presence of longchain alcohols in relatively high amounts also seems to be of taxonomic value for Moraxella (Rossau et al., 1991). On the other hand, [Alysiella] sp. IAM 14971 does not contain significant $18: 1 \omega 7 c$, which is different from other species of the genus Moraxella. The $\mathrm{G}+\mathrm{C}$ content the DNA of [Alysiella] sp. IAM 14971 is $40.5 \mathrm{~mol} \%$ (Rossau et al., 1991), which is $5 \%$ lower than that of the genus Alysiella but similar to that of the genus Moraxella.

The 16S rRNA gene sequences of 12 species of the genus Moraxella and related genera of the family Moraxellaceae were analysed and a phylogenetic tree was constructed using the neighbour-joining method with 1181 nucleotides positions calculated (Fig. 2). These comparisons revealed that [Alysiella] sp. IAM 14971 should be included within the genus Moraxella (96-97\% sequence similarity compared with $93 \%$ similarity to members of the genus Psychrobacter). The phylogenetic analysis of 16S rRNA gene sequences was consistent with the results of DNA-rRNA hybridization, indicating that [Alysiella] sp. IAM 14971 clustered together with the $M$. (M.) lacunata subgroup within the genus Moraxella (Rossau et al., 1991). The significant node (100\% bootstrap value) positioned at the branch point between [Alysiella] sp. IAM 14971 and the main Moraxella cluster indicated a close phylogenetic relationship. Therefore, [Alysiella] sp. IAM 14971 is suggested to represent a novel species of the genus Moraxella, Moraxella oblonga sp. nov. (type strain, IAM $14971^{\mathrm{T}}=$ ATCC $29468^{\mathrm{T}}$ ). The cellular morphology of cocci in chains clearly differentiates this novel species from other species of the genus Moraxella.

Similar to other species of the genus Moraxella, which can be isolated from the mucous membranes of man and/or other animals and can typically grow on ordinary blood agar medium at $37^{\circ} \mathrm{C}$, M. oblonga IAM $14971^{\mathrm{T}}$ was isolated from the oral cavity of a sheep. M. oblonga IAM $14971^{\mathrm{T}}$ has characteristics similar to those of other members of the genus Moraxella (Bøvre, 1984). Its cells are aerobic, oxidasepositive, catalase-positive cocci. No acid is produced from glucose, and negative reactions result with indole and urea. The cells have a signature fatty acid composition with 16:0 $\mathrm{N}$ alcohol as one of the major fatty acids, and the major hydroxy fatty acid is $3 \mathrm{OH}-12: 0$. The $\mathrm{G}+\mathrm{C}$ content of the DNA is $40.5 \mathrm{~mol} \%$, which is within the typical range of Moraxella species (40-45.0 \%; Bøvre, 1984).

\section{Description of Moraxella oblonga sp. nov.}

Moraxella oblonga (ob.lon'ga. L. fem. adj. oblonga elongated, stretched out).

Cells are cocci that are organized in chains of $\geqslant 30 \mu \mathrm{m}$ in length. Cells are $0 \cdot 48-1 \cdot 2 \mu \mathrm{m}$ in diameter. Catalase- and 
Table 1. Phenotypic features of Moraxella oblonga sp. nov. IAM $14971^{\top}$ and related bacteria

Taxa: 1, M. oblonga IAM $14971^{\mathrm{T}}$; 2, A. filiformis IAM $14895^{\mathrm{T}}$; 3, M. (M.) bovis CCUG $2133^{\mathrm{T}}$; 4, M. (M.) lacunata CCUG $4441^{\mathrm{T}}$; 5, M. (B.) catarrhalis ATCC $25238^{\mathrm{T}}$. Data for Moraxella species are from Bøvre (1984), Jannes et al. (1993) and Vandamme et al. (1993). +, Positive reaction; -, negative reaction; ND, no data. All the strains are catalase- and oxidase-positive, and do not hydrolyse urea or produce indole; their major hydroxy fatty acid is $3 \mathrm{OH}-12: 0$, and they have ubiquinone Q-8.

\begin{tabular}{|c|c|c|c|c|c|}
\hline Characteristics & 1 & 2 & 3 & 4 & 5 \\
\hline Isolation & Sheep, oral & Sheep, oral & Horse & Human & Human \\
\hline Morphology & Cocci in chains & Filamentous & Rods & Rods & Cocci \\
\hline Nitrate reduction & - & - & + & + & - \\
\hline \multicolumn{6}{|l|}{ Acid production from: } \\
\hline Glucose & - & + & - & - & - \\
\hline \multicolumn{6}{|l|}{ Hydrolysis of: } \\
\hline Lysine & - & - & + & + & + \\
\hline Ornithine & - & - & ND & ND & ND \\
\hline Arginine & + & - & + & - & - \\
\hline Gelatin & + & - & + & - & - \\
\hline Major fatty acid composition & $\begin{array}{c}16: 0 N \\
\text { alcohol, } 16: 0\end{array}$ & $\begin{array}{c}16: 1 \omega 7 c \\
16: 0\end{array}$ & $\begin{array}{l}18: 1 \text { cis } 9 \\
16: 1 \text { cis } 9\end{array}$ & $\begin{array}{l}18: 1 \text { cis } 9 \\
16: 1 \text { cis } 9\end{array}$ & $\begin{array}{l}18: 1 \text { cis } 9, \\
16: 1 \text { cis } 9\end{array}$ \\
\hline $\mathrm{G}+\mathrm{C}$ content $(\mathrm{mol} \%)$ & $40 \cdot 5$ & $45 \cdot 4$ & $42 \cdot 5$ & $43 \cdot 9$ & $41 \cdot 0$ \\
\hline
\end{tabular}

oxidase-positive. Nitrate is not reduced. Acid is produced from mannitol, adonitol, inositol, rhamnose, sucrose, arabinose and maltose, but not from glucose. Hydrolyses arginine and liquefies gelatin. Does not hydrolyse urea or lysine, decarboxylate ornithine, or produce indole. The major cellular fatty acids are 16:0,16:0 N alcohol and

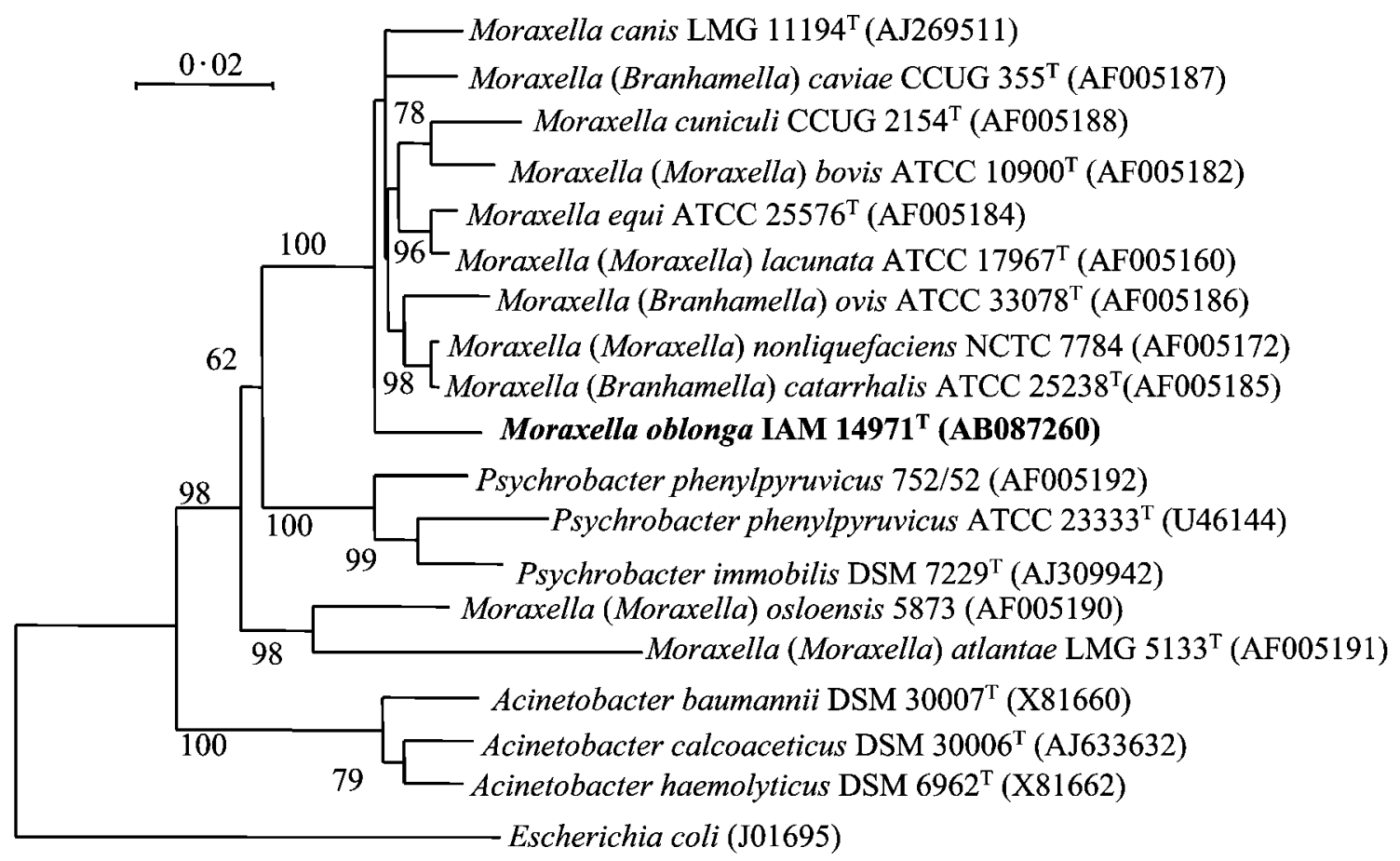

Fig. 2. Neighbour-joining tree, constructed from $16 \mathrm{~S}$ rRNA gene sequences, showing the phylogenetic position of Moraxella oblonga sp. nov. IAM $14971^{\top}$ compared with species of the genus Moraxella and related bacteria. Numbers at the nodes indicate bootstrap values (1000 replicates); only values greater than $60 \%$ are shown. 
$16: 1 \omega 7 c$, and the major hydroxy fatty acid is $3 \mathrm{OH}-12: 0$. The major quinone system is ubiquinone $\mathrm{Q}-8$. The $\mathrm{G}+\mathrm{C}$ content of the DNA is $40.5 \mathrm{~mol} \%$.

The type strain is IAM $14971^{\mathrm{T}}$ ( = ATCC $29468^{\mathrm{T}}$ ), which was isolated from the oral cavity of a sheep.

\section{References}

Bøvre, K. (1979). Proposal to divide the genus Moraxella Lwoff 1939 emend. Henriksen and Bøvre 1968 into two subgenera, subgenus Moraxella (Lwoff 1939) Bøvre 1979 and subgenus Branhamella (Catlin 1970) Bøvre 1979. Int J Syst Bacteriol 29, 403-406.

Bøvre, K. (1984). Genus II. Moraxella Lwoff 1939, 173 emend. Henriksen and Bøvre 1968, 391 ${ }^{A L}$. In Bergey's Manual of Systematic Bacteriology, vol. 1, pp. 296-302. Edited by N. R. Krieg \& J. G. Holt. Baltimore: Williams \& Wilkins.

Felsenstein, J. (1985). Confidence limits on phylogenies: an approach using the bootstrap. Evolution 39, 783-791.

Gherna, R., Pienta, P. \& Cote, R. (1989). American Type Culture Collection (ATCC) Catalogue of Bacteria and Phages, 17th edn, p.15.

Jannes, G., Vaneechoutte, M., Lannoo, M., Gillis, M., Vancanneyt, M., Vandamme, P., Verscharegen, G., Van Heuverswyn, H. \& Rossau, R. (1993). Polyphasic taxonomy leading to the proposal of Moraxella canis sp. nov. for Moraxella catarrhalis-like strains. Int J Syst Bacteriol 43, 438-449.

Kimura, M. (1980). A simple method for estimating evolutionary rates of base substitutions through comparative studies of nucleotide sequences. J Mol Evol 16, 111-120.
Rossau, R., Van Landschoot, A., Mannheim, W. \& De Ley, J. (1986). Inter- and intrageneric similarities of ribosomal ribonucleic acid cistrons of the Neisseriaceae. Int J Syst Bacteriol 36, 323-332.

Rossau, R., Vandenbussche, G., Thielemans, S., Segers, P., Grosch, H., Göthe, E., Mannheim, W. \& De Ley, J. (1989). Ribosomal ribonucleic acid cistron similarities and deoxyribonucleic acid homologies of Neisseria, Kingella, Eikenella, Simonsiella, Alysiella, and Centers for Disease Control groups EF-4 and M-5 in the emend family Neisseriaceae. Int J Syst Bacteriol 39, 185-198.

Rossau, R., Van Landschoot, A., Gillis, M. \& De Ley, J. (1991). Taxonomy of Moraxellaceae fam. nov., a new bacterial family to accommodate the genera Moraxella, Acinetobacter, and Psychrobacter and related organisms. Int J Syst Bacteriol 41, 310-319.

Saitou, N. \& Nei, M. (1987). The neighbor-joining method: a new method for reconstructing phylogenetic trees. Mol Biol Evol 4, 406-425.

Swofford, D. L. (1998). PAUP* - Phylogenetic Analysis Using Parsimony (* and other methods), version 4. Sunderland, MA: Sinauer Associates.

Thompson, J. D., Higgins, D. G. \& Gibson, T. J. (1994). CLUSTAL W: improving the sensitivity of progressive multiple sequence alignment through sequence weighting, position-specific gap penalties and weight matrix choice. Nucleic Acids Res 22, 4673-4680.

Vandamme, P., Gillis, M., Vancanneyt, M., Hoste, B., Kersters, K. \& Falsen, E. (1993). Moraxella lincolnii sp. nov., isolated from the human respiratory tract, and reevaluation of the taxonomic position of Moraxella osloensis. Int J Syst Bacteriol 43, 474-481.

Xie, C.-H. \& Yokota, A. (2003). Phylogenetic analyses of Lampropedia hyalina based on the 16S rRNA gene sequence. J Gen Appl Microbiol 49, 345-349. 